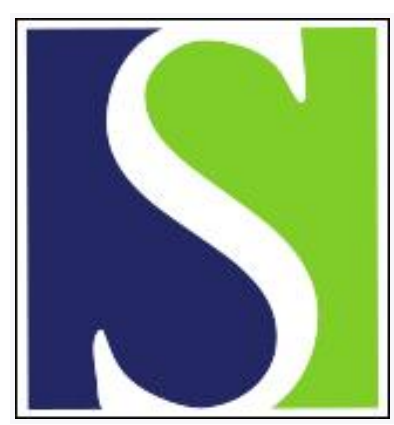

Scand J Work Environ Health 1981;7(3):214-222

https://doi.org/10.5271/sjweh.3114

Issue date: Sep 1981

Influence of fluoride recovery alumina on the work environment and the health of aluminum potroom workers by Eduard W, Lie A

Affiliation: Institute of Occupational Health, Oslo 1, Norway.

Refers to the following texts of the Journal: 1978;4(3):224-236 1978;4(3):212-223

Key terms: acute health complaint; aluminum potroom; aluminum potroom worker; chronic pulmonary disease; dust exposure; exposure; fluoride recovery alumina; health; health complaint; PAH; particle size; polycyclic aromatic hydrocarbon; primary aluminum production; trace element; work environment; worker

This article in PubMed: www.ncbi.nlm.nih.gov/pubmed/20120587

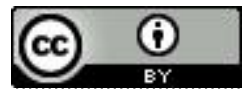




\title{
Influence of fluoride recovery alumina on the work environment and the health of aluminum potroom workers
}

\author{
by Wijnand Eduard, Arve Lie '
}

\begin{abstract}
EDUARD W, LIE A. The influence of fluoride recovery alumina on the work environment and the health of aluminum potroom workers. Scand $j$ work environ health 7 (1981) 214-222. Dust exposure and health complaints were recorded by means of personal samplers and a questionnaire for potroom workers in a primary aluminum plant situated at the west coast of Norway. The study revealed a higher dust exposure and a higher prevalence of acute health complaints during a period when fluoride recovery alumina from a dry-cleaning process was used compared to another period when pure alumina was used. Weather conditions and work conditions were otherwise similar during the two periods. This finding indicates that the use of recovery alumina increases the pollution of the work atmosphere and thereby causes more health complaints. The study also revealed a higher prevalence of pulmonary symptoms of a chronic recurrent nature than expected, in spite of the thorough selection which takes place before and during employment, and may therefore indicate that potroom workers are under the risk of developing chronic pulmonary disease.
\end{abstract}

Key words: acute health complaints, chronic pulmonary disease, dust exposure, particle size, polycyclic aromatic hydrocarbons, primary aluminum production, trace elements.

Primary aluminum production is based on electrolytic reduction of alumina in a cryolite melt taking place in large potrooms.

The work environment includes exposure to particulate and gaseous fluorides, alumina, sulfur dioxide, carbon monoxide, polycyclic aromatic hydrocarbons (PAH), trace elements, heat stress, heavy physical work, magnetic fields, vibration from pneumatic tools, and shift work.

Health hazards in the primary aluminum industry include, besides accidents, respiratory illness in particular. Occupational asthma was described in Norway in 1936 and has been verified in several studies since then. Epidemiologic research has also indicated an increased mortality from cancer and pulmonary emphysema (10). Whereas pulmonary fibrosis (alumi-

1 Institute of Occupational Health, Oslo, Norway.

Reprint requests to: $\mathrm{Mr} \mathrm{W}$ Eduard, Institute of Occupational Health, PO Box 8149, DEP, Oslo 1 , Norway. nosis) and bone fluorosis were previously considered to be health problems, this no longer seems to be the case due to improvements in the work environment (6). There may also be an increased risk of developing chronic obstructive lung disease, but this question is still being disputed (6). Acute respiratory complaints are also well known and have been attributed to exposure to dust and gaseous and particulate fluorides. A dose-response relationship between personal exposure to total dust and subjective acute airway complaints has been shown (11).

To minimize the emissions of fluorides and sulfur dioxide to the external environment, new technology has been introduced. Fluorides are recovered from the potgas by adsorption to alumina in a dry scrubber and recycled to the primary aluminum production. Besides the environmental advantages this process also has great economic ones.

A previous study has indicated however an infavorable development in the work 
environment when recycled alumina, hereafter called "recovery alumina," is used. An increased prevalence of acute respiratory complaints and a higher dust exposure due to recovery alumina have been reported $(4,11)$. An increased prevalence of dermatitis has also been found $(7,8)$.

In 1979 a conflict arose between the employer and employees due to the deterioration of the work environment in a Søderberg aluminum potroom after the introduction of a fluoride recovery process in 1974.

The aim of the present investigation was to study the influence of fluoride recovery alumina on dust exposure and on the short-time health effects of aluminum potroom operators.

\section{Methods}

The investigation was carried out during two periods, each lasting $8 \mathrm{~d}$. Recovery alumina was used during the first period and pure alumina during the second. The investigation included the same workers during both periods.

Each worker wore a personal dust sampler (Casella T $13050 / 1$, capacity $2 \mathrm{l} / \mathrm{min}$ ) throughout one 8-h shift in each of the two periods. At the end of the shift they handed in the dust sampler and completed a short questionnaire. The same questionnaire was thus filled out twice by each operator.

The dust samples were collected on Millipore $0.8-\mu \mathrm{m}$ AAWP and Gelman Acropore AN-800 filters. All samples were analyzed for total dust. A randomized selection of the dust samples was analyzed for particle size by low-temperature ashing of the Millipore filters and counting with a Coulter counter model TA II. A randomized selection of dust samples, which were collected on Gelman Acropore AN800 filters, were analyzed for polycyclic aromatic hydrocarbons (PAH) by gas chromatography and high-pressure liquid chromatography $(1,2)$.

Exposure to trace elements was estimated by atomic absorption spectrometry (AAS) and induced coupled plasma emission spectrometry (ICPES) of high volume samples collected on Gelman Acropore AN-5000 filters.

The questionnaire contained seven ques- tions regarding acute work-related health complaints (table 4) and four questions regarding other respiratory symptoms (table 8) (3). Information about smoking habits, the use of personal protective equipment, and operational problems and a subjective evaluation of the dust and gas exposure during the shift were also recorded.

A symptom score was designed, based on the answers, scoring 3 points for answers of the category "yes, much," 1 point for the category "yes, a little" and 0 points for "no" answers. The scores for all seven answers were added up to form a personal symptom score.

The operators were divided into two groups, pot operators and other operators. "Other operators" included foremen and workers who carried out operations such as stud pulling, stud cleaning, metal tapping, charging alumina respective anode mass, and crust breaking.

To ensure a relevant comparison between periods the following protocol was used:

(a) Each period lasted eight workdays, with one week in between to ensure that all alumina was replaced.

(b) The same shipload of alumina was used throughout the investigation.

(c) Operating conditions of the pots were recorded by a team representing both the employer and the employees.

(d) The weather conditions were recorded.

(e) The four questions regarding respiratory symptoms of a chronic recurrent nature were expected to be answered in the same way during both periods. These replies were used as a control for a possible bias in the replies regarding acute work-related complaints.

(f) The operators filled out the questionnaire to eliminate the possible influence of an interviewer.

\section{Results}

A total of 177 workers participated in the investigation, and of these 145 participated throughout both the recovery 
alumina and the pure alumina period. One hundred and twenty-three operators did the same type of work during both periods; 60 were pot operators and 63 other potroom workers. One hundred and fiftynine participated during the recovery alumina period, and 163 during the pure alumina period.

\section{Operating and weather conditions}

Weather conditions were more favorable during the recovery alumina period, whereas the number of plugged burners was higher during the same period. The number of open pots, anode effects, and other operating conditions were of the same order during the two work periods.

\section{Dust exposure}

The median dust exposure was $5.0 \mathrm{mg} / \mathrm{m}^{3}$ during the recovery alumina period and $4.0 \mathrm{mg} / \mathrm{m}^{3}$ during the pure alumina period. The difference was statistically significant (table 1). The difference between the periods was larger for pot operators than for other operators. Sixty pot operators who performed the same job operation both periods had a dust exposure of $7.6 \mathrm{mg} / \mathrm{m}^{3}$ during the recovery alumina period compared to $5.4 \mathrm{mg} / \mathrm{m}^{3}$ during the pure alumina period (table 2). The difference was statistically significant. The corresponding group of 63 other potroom workers had a median dust exposure of $3.4 \mathrm{mg} / \mathrm{m}^{3}$ during the recovery alumina period and 2.9 $\mathrm{mg} / \mathrm{m}^{3}$ during the pure alumina period. This difference was not statistically significant.

The results of the particle size analysis of the dust samples from the pot operators and other operators are shown in fig 1 and 2 . The concentrations of all particle size classes were higher in the recovery alumina period than in the pure alumina period.

The differences were statistically significant for dust particles smaller than $5 \mu \mathrm{m}$ for both pot operators and other potroom workers, and for dust particles $20-30 \mu \mathrm{m}$ in size and particles larger than $30 \mu \mathrm{m}$ for pot operators only. The differences in dust exposure between the pot operators and other operators increased as the particle size increased.

Exposure to PAH revealed no significant differences between periods nor between

Table 1. Dust exposure $\left(\mathrm{mg} / \mathrm{m}^{3}\right)$ during both periods. The table includes all operators.

\begin{tabular}{|c|c|c|c|c|c|c|}
\hline & \multicolumn{3}{|c|}{ Recovery alumina } & \multicolumn{3}{|c|}{ Pure alumina } \\
\hline & Median & Range & $\begin{array}{c}\text { Number of } \\
\text { operators }\end{array}$ & Median & Range & $\begin{array}{c}\text { Number of } \\
\text { operators }\end{array}$ \\
\hline $\begin{array}{l}\text { Pot operators } \\
\text { Other operators }\end{array}$ & $\begin{array}{l}7.6 \\
3.4\end{array}$ & $\begin{array}{l}1.5-135.0 \\
0.2-15.2\end{array}$ & $\begin{array}{l}81 \\
78\end{array}$ & $\begin{array}{l}5.4 \\
2.9\end{array}$ & $\begin{array}{l}2.2-13.0 \\
1.0-23.8\end{array}$ & $\begin{array}{l}81 * \\
82\end{array}$ \\
\hline Total & 5.0 & $0.2-135.0$ & 159 & 4.0 & $1.0-23.8$ & $163 * * *$ \\
\hline
\end{tabular}

* $\mathrm{p}<0.05,{ }^{* * *} \mathrm{p}<0.001$ (Mann-Whitney test).

Table 2. Dust exposure $\left(\mathrm{mg} / \mathrm{m}^{3}\right)$ during both periods. The table includes operators performing the same job operation during both periods.

\begin{tabular}{|c|c|c|c|c|c|c|}
\hline & \multicolumn{3}{|c|}{ Recovery alumina } & \multicolumn{3}{|c|}{ Pure alumina } \\
\hline & Median & Range & $\begin{array}{c}\text { Number of } \\
\text { operators }\end{array}$ & Median & Range & $\begin{array}{c}\text { Number of } \\
\text { operators }\end{array}$ \\
\hline $\begin{array}{l}\text { Pot operators } \\
\text { Other operators }\end{array}$ & $\begin{array}{l}7.6 \\
3.4\end{array}$ & $\begin{array}{l}2.6-135.0 \\
0.2-15.2\end{array}$ & $\begin{array}{l}60 \\
63\end{array}$ & $\begin{array}{l}5.4 \\
2.9\end{array}$ & $\begin{array}{l}2.2-13.0 \\
1.0-23.8\end{array}$ & $\begin{array}{l}60 * * * \\
63\end{array}$ \\
\hline Total & 5.4 & $0.2-135.0$ & 123 & 4.0 & $1.0-23.8$ & $123 * * *$ \\
\hline
\end{tabular}

*** $p<0.001$ (Wilcoxon matched pair test). 
pot operators and other potroom workers. Of the samples $60 \%$ exceeded the Norwegian hygienic standard of $40 \mu \mathrm{g}$ of $\mathrm{PAH} / \mathrm{m}^{3}$ (table 3 ).

The exposure to trace elements was far below the hygienic standards for the respective elements. The following elements were determined: arsenic, cadmium, cobalt, chromium, copper, iron, gallium, indium, manganese, molybdenum, nickel, lead, tin, vanadium and zinc.

\section{Acute health complaints}

A higher prevalence of work-related symptoms was found during the recovery alumina period than during the pure alumina period (table 4). Based on the questions concerning these symptoms, a symptom score was calculated. The mean symptom score was higher for the recovery alumina period than for the pure alumina period (table 5). The difference in symptom
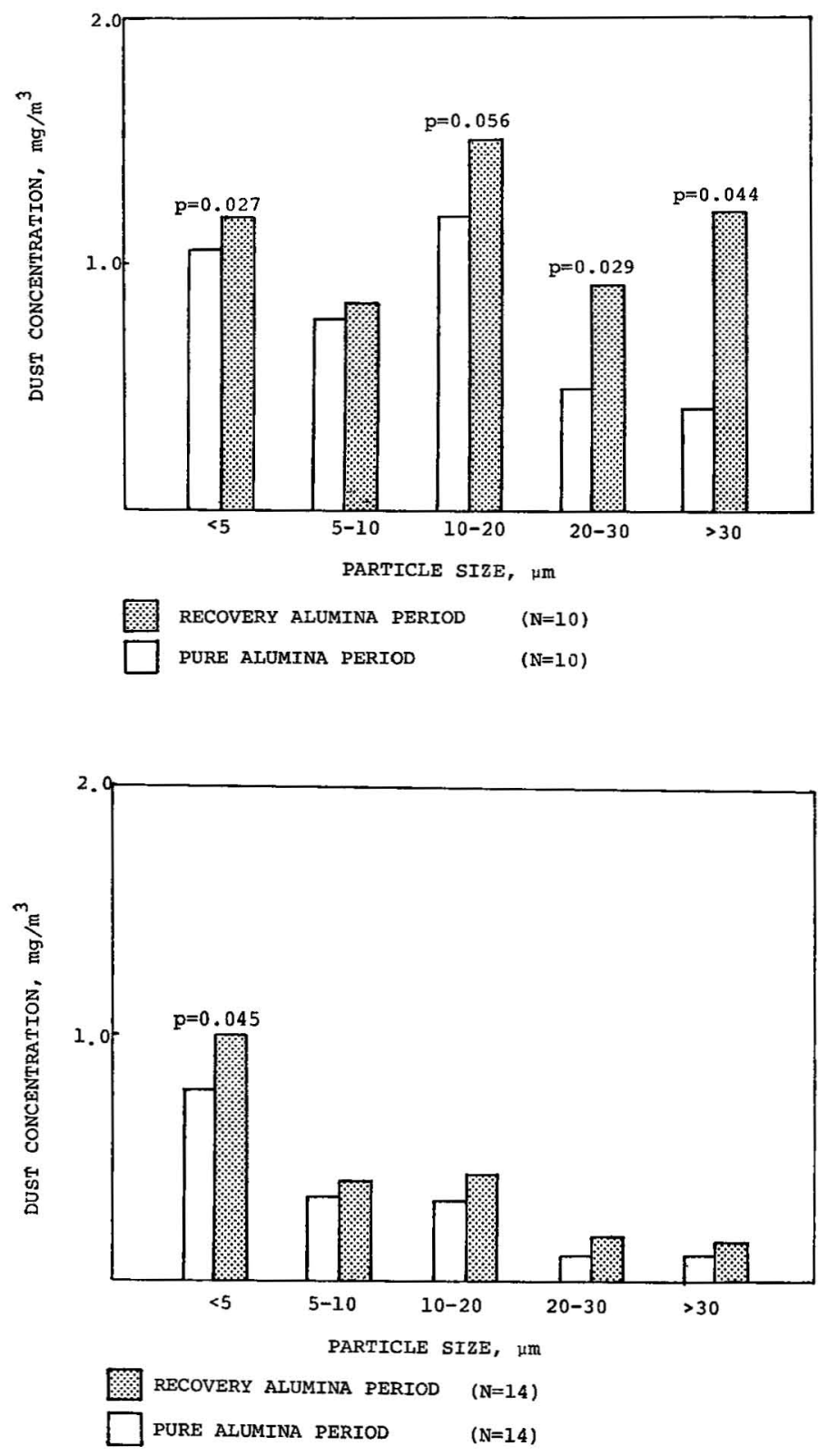

Fig 1. Median concentration of inorganic dust with different particle sizes during the recovery alumina and pure alumina period. The dust samples derive from 10 pot operators who performed the same job operations during both periods. The pot operators were randomly selected. $p$-Values determined with the Mann-Whitney test.

Fig 2. Median concentration of inorganic dust with different particle sizes during the recovery alumina and pure alumina period. The dust samples derive from 14 other potroom workers who performed the same job operations during both periods. The operators were randomly selected. p-Value determined with the Mann-Whitney test. 
Table 3. Polycyclic aromatic hydrocarbon exposure $\left(\mu \mathrm{g} / \mathrm{m}^{3}\right)$ during both periods. The table includes operators performing the same job operation during both periods.

\begin{tabular}{|c|c|c|c|c|c|c|}
\hline & \multicolumn{3}{|c|}{ Pure alumina period } & \multicolumn{3}{|c|}{ Recovery alumina period } \\
\hline & Median & Range & $\begin{array}{l}\text { Number of } \\
\text { operators }\end{array}$ & Median & Range & $\begin{array}{l}\text { Number of } \\
\text { operators }\end{array}$ \\
\hline $\begin{array}{l}\text { Pot operators } \\
\text { Other operators }\end{array}$ & $\begin{array}{l}45 \\
48\end{array}$ & $\begin{array}{l}28-150 \\
15-160\end{array}$ & $\begin{array}{r}9 \\
13\end{array}$ & $\begin{array}{l}51 \\
38\end{array}$ & $\begin{array}{l}31-130 \\
12-100\end{array}$ & $\begin{array}{r}9 \\
13\end{array}$ \\
\hline
\end{tabular}

Table 4. Prevalence $(\%)$ of work-related symptoms during both periods. The table includes alt operators.

\begin{tabular}{|c|c|c|c|c|}
\hline \multirow[t]{2}{*}{ Symptoms } & \multicolumn{2}{|c|}{$\begin{array}{l}\text { Recovery alumina } \\
\text { period }(\mathrm{N}=159)\end{array}$} & \multicolumn{2}{|c|}{$\begin{array}{l}\text { Pure alumina } \\
\text { period }(N=163)\end{array}$} \\
\hline & Much & A little & Much & A little \\
\hline Irritation or discomfort from the nose & 5 & 34 & 2 & 23 \\
\hline Irritation or discomfort from the throat & 3 & 32 & 2 & 25 \\
\hline Irritation or discomfort from the eyes & 4 & 26 & 1 & 20 \\
\hline Dry cough & 4 & 22 & 1 & 18 \\
\hline Cough with phlegm & 1 & 25 & 1 & 17 \\
\hline Breathlessness & 1 & 25 & 1 & 22 \\
\hline Wheezing from the chest & 1 & 16 & 1 & 14 \\
\hline
\end{tabular}

Table 5. Symptom score a during both periods. The table includes all operators.

\begin{tabular}{|c|c|c|c|c|c|c|}
\hline \multirow[b]{3}{*}{$\begin{array}{l}\text { Pot operators } \\
\text { Other operators }\end{array}$} & \multicolumn{3}{|c|}{ Recovery alumina period } & \multicolumn{3}{|c|}{ Pure alumina period } \\
\hline & Mean & Range & $\begin{array}{l}\text { Number of } \\
\text { operators }\end{array}$ & Mean & Range & $\begin{array}{l}\text { Number of } \\
\text { operators }\end{array}$ \\
\hline & $\begin{array}{l}2.58 \\
2.14\end{array}$ & $\begin{array}{l}0-15 \\
0-14\end{array}$ & $\begin{array}{l}81 \\
78\end{array}$ & $\begin{array}{l}1.69 \\
1.51\end{array}$ & $\begin{array}{l}0-11 \\
0-11\end{array}$ & $\begin{array}{l}81 * \\
82\end{array}$ \\
\hline Total & 2.37 & $0-15$ & 159 & 1.60 & $0-11$ & $163 *$ \\
\hline
\end{tabular}

a The sum total of seven questions regarding acute work-related health complaints. Scoring: $3=$ yes, much; $1=$ yes, a little, $0=$ no.

* $\mathrm{p}<0.05$ (Mann-Whitney test).

Table 6. Subjective symptom score a in relation to dust exposure during both periods. The table includes all operators.

\begin{tabular}{|c|c|c|c|c|c|c|}
\hline \multirow{2}{*}{$\begin{array}{l}\text { Dust exposure } \\
\left(\mathrm{mg} / \mathrm{m}^{3}\right)\end{array}$} & \multicolumn{3}{|c|}{ Recovery alumina } & \multicolumn{3}{|c|}{ Pure alumina } \\
\hline & Mean & Range & $\begin{array}{c}\text { Number of } \\
\text { operators }\end{array}$ & Mean & Range & $\begin{array}{c}\text { Number of } \\
\text { operators }\end{array}$ \\
\hline $\begin{array}{l}0-2.4 \\
2.5-4.9 \\
5.0-7.4 \\
7.5-9.9 \\
\geq 10.0\end{array}$ & $\begin{array}{l}2.46 \\
2.51 \\
2.07 \\
2.71 \\
2.20\end{array}$ & $\begin{array}{l}0-14 \\
0-11 \\
0-8 \\
0-8 \\
0-15\end{array}$ & $\begin{array}{l}24 \\
55 \\
31 \\
14 \\
35\end{array}$ & $\begin{array}{l}1.14 \\
1.65 \\
2.00 \\
1.00 \\
1.25\end{array}$ & $\begin{array}{l}0-11 \\
0-8 \\
0-11 \\
0-5 \\
0-5\end{array}$ & $\begin{array}{r}22 \\
86 \\
38 \\
13 \\
4\end{array}$ \\
\hline Total & 2.37 & $0-15$ & 159 & 1.60 & $0-11$ & $163 *$ \\
\hline
\end{tabular}

a The sum total of seven questions regarding acute work-related health complaints. Scoring: $3=$ yes, much; $1=$ yes: a little; $0=$ no.

* $\mathrm{p}<0.05$ (Mann-Whitney test). 
score between the two periods was more pronounced among pot operators than among the other potroom workers. The pot operators also had a higher mean symptom score than the other potroom workers for both periods.

Table 6 shows that no dose-response relationship was found within each of the periods. Applying another approach to this question, using every worker as his own control, we were able to find a relationship between differences in dust exposure and differences in symptom scores between the two periods (table 7).

\section{Other respiratory symptoms}

The agreement was good between the answers given regarding other respiratory symptoms during the two periods.

One hundred and seventy-seven workers completed the questionnaire once or twice. Their prevalence of respiratory symptoms of a chronic recurrent nature are given in table 8. The figures derive from the first time they answered the questionnaire. These results were compared to the prevalence of the same respiratory symptoms in a standard male population of 8,154 living in Oslo, given the same questions in a postal questionnaire (3). The "expected" figures in table 8 were calculated from the Oslo study after standardization for age and smoking habits. The prevalence of wheezing was sig- nificantly higher than expected, irrespective of smoking habits. The prevalence of breathlessness was higher than expected only for nonsmokers. Generally the differences between the observed and the expected prevalences seemed to be relatively higher for the nonsmoking group than for smokers.

\section{Other questions}

The dust exposure was characterized as heavy by 64 workers $(40 \%)$ during the period with recovery alumina, whereas 31 workers $(19 \%)$ reported that this was the case in the period with pure alumina (table 9). The difference was statistically significant.

Table 7. Correlation between dust exposure and the symptom score during both periods. The table includes 123 workers performing the same job operations in both periods.

\begin{tabular}{lcc}
\hline & $\begin{array}{c}\text { Number of workers } \\
\text { with highest } \\
\text { exposure }\end{array}$ \\
\cline { 2 - 3 } $\begin{array}{l}\text { Number of workers with } \\
\text { highest symptom score }\end{array}$ & $\begin{array}{c}\text { Recovery } \\
\text { alumina } \\
\text { period }\end{array}$ & $\begin{array}{c}\text { Pure } \\
\text { plumina } \\
\text { period }\end{array}$ \\
\hline Recovery alumina period & 36 & 12 \\
No difference & 35 & 14 \\
Pure alumina period & 12 & 14 \\
\hline
\end{tabular}

$\chi^{2}=6.97,2 \mathrm{df}, p<0.05$.

Table 8. Observed and expected number of other respiratory symptoms. The table includes the results from the first time the questionnaire was completed.

\begin{tabular}{|c|c|c|c|c|}
\hline \multirow{2}{*}{ Symptoms } & \multicolumn{2}{|c|}{$\begin{array}{l}\text { Smokers a } \\
(N=119)\end{array}$} & \multicolumn{2}{|c|}{$\begin{array}{c}\text { Nonsmokersa } \\
(\mathrm{N}=59) \\
\end{array}$} \\
\hline & 0 & $E$ & 0 & $\mathrm{E}$ \\
\hline $\begin{array}{l}\text { Do you usually cough and clear your throat in the } \\
\text { morning? } \\
\text { When you cough or clear your throat, do you }\end{array}$ & 40 & 46.4 & 7 & 7.4 \\
\hline $\begin{array}{l}\text { usually bring up phlegm? } \\
\text { Are you more breathless than people of your own }\end{array}$ & 43 & 39.3 & 13 & 8.7 \\
\hline age when walking uphill? & 41 & 32.3 & $16 *$ & 8.7 \\
\hline Have you ever had wheezing in your chest? & $44^{*}$ & 32.2 & $18 * * *$ & 5.7 \\
\hline
\end{tabular}

a $\mathrm{O}=$ observed number of persons with symptoms; $\mathrm{E}=$ expected number of persons with symptoms, calculated from the report of Gulsvik (4); $\mathrm{N}=$ total number of persons within each category. An approximate $\chi^{2}$ test: $\chi^{2}=(\mathrm{O}-\mathrm{E})^{2} / \mathrm{E}, 1 \mathrm{df}$ [see Miettinen (9)].

$* \mathrm{p}<0.05, * * * \mathrm{p}<0.001$. 
Table 9. Responses to other parts of the questionnaire during both periods. The table includes all operators.

\begin{tabular}{|c|c|c|c|c|}
\hline \multirow[t]{2}{*}{ Question } & \multicolumn{2}{|c|}{$\begin{array}{l}\text { Recovery alumina period } \\
\qquad(\mathrm{N}=159)\end{array}$} & \multicolumn{2}{|c|}{$\begin{array}{l}\text { Pure alumina period } \\
\qquad(N=163)\end{array}$} \\
\hline & Yes, much & Yes, a little & Yes, much & Yes, a little \\
\hline \multirow[t]{2}{*}{$\begin{array}{l}\text { During work today, were you exposed } \\
\text { to dust? } \\
\text { During work today, were you exposed } \\
\text { to gas? }\end{array}$} & $\begin{array}{l}63(40 \%) \\
31(20 \%)\end{array}$ & $\begin{array}{l}88(55 \%) \\
104(65 \%)\end{array}$ & $\begin{array}{l}31(19 \%) \\
25(15 \%)\end{array}$ & $\begin{array}{l}121(74 \%) * * * \\
111(68 \%)\end{array}$ \\
\hline & \multicolumn{2}{|c|}{ Yes } & \multicolumn{2}{|c|}{ Yes } \\
\hline $\begin{array}{l}\text { Use of gas mask, dust mask or both? } \\
\text { Did you smoke at work today? } \\
\text { Did work conditions differ from normal? }\end{array}$ & \multicolumn{2}{|c|}{$\begin{aligned} 123 & (77 \%) \\
100 & (63 \%) \\
17 & (11 \%)\end{aligned}$} & \multicolumn{2}{|c|}{$\begin{array}{r}120(74 \%) \\
111(68 \%) \\
16(10 \%)\end{array}$} \\
\hline
\end{tabular}

*** $\mathrm{p}<0.001$ (Chi-square test, $1 \mathrm{df}$ ).

The subjective evaluation of the dust exposure also showed good agreement with the measured results. There were only minor differences in the evaluation of exposure to gases between the two periods (table 9).

The use of personal protective equipment (gas mask, dust mask), smoking habits, and the evaluation of the work conditions were of the same order during the two periods (table 9 ).

\section{Discussion}

The influence of differences in work and weather conditions on the results was considered negligible.

The operators had a higher dust exposure during the period when recovery alumina was used. This result is consistent with the findings of a previous investigation (4). The higher dust exposure from recovery alumina may be explained by a change in the properties of the dust particles by adsorption in the dry-cleaning process. This procedure may lower the adhesion forces between the dust particles.

The pot operators working close to the pots were exposed to a higher concentration of both large and small particles during the recovery alumina period. This was not the case for large particles for the other operators, probably due to the higher sedimentation rate of large particles and a greater distance from the pots. Some of the other operators were also protected from dust exposure, as they worked in closed cabins.

PAH exposure probably derives mainly from the Søderberg anodes, and only to a minor extent from PAH contamination in the recovery alumina.

The good agreement between the two periods with respect to respiratory symptoms of a chronic recurrent nature indicates that the workers filled out the questionnaires conscientiously. We therefore believe that a possible bias because of the conflict situation mentioned earlier was of negligible importance.

The higher prevalence of acute health complaints during the recovery alumina period compared to the pure alumina period is consistent with the measured dust exposure. This difference may partly be due to the higher dust exposure during the recovery alumina period as indicated in table 7. Since the symptom score was however higher during the recovery alumina period irrespective of the dust exposure level (table 6), a greater irritation is indicated for the recovery alumina than for the pure alumina, and thereby adverse effects appear. During the recycling process various contaminants, like fluorides and sulfur dioxide, are adsorbed on the alumina. This phenomenon may explain the greater irritation caused by recovery alumina than pure alumina.

The lack of a dose-response relationship between dust exposure and acute health complaints within each of the periods was further analyzed. Workers reporting 
"other respiratory symptoms" had a much higher prevalence of acute work-related symptoms than the other workers had. The same group had a much lower exposure to dust than the other workers. This situation may have been due to selection factors, and it may explain why a doseresponse relationship was not found within each of the periods.

The use of personal protective equipment like gas masks and dust masks was more frequent among the highly exposed workers and may also explain why a doseresponse relationship was not found within each of the periods. By comparing each worker with himself during the two periods, we were able to eliminate the mentioned selection factors. By restricting the analysis to 123 workers who did the same job operations during both periods, we were able to show a relationship between dust exposure and acute health complaints, as shown in table 7 .

The prevalence of other pulmonary symptoms was somewhat higher than expected (3), and the observed-expected ratio was relatively higher for nonsmokers than smokers. Unfortunately our information on smoking habits was based solely on the question "Did you smoke at work today?" A previous Norwegian study from the aluminum industry has shown that smoking during the day is highly correlated to smoking as a habit (7). The nonsmoking group in our investigation probably contains both persons who have never smoked, some exsmokers, and possibly a few very light smokers. The "expected" prevalence given in table 8 concerning nonsmokers is based however on persons who have never smoked and exsmokers from the Oslo study (3). The reason for smokers coming out relatively more favorably than nonsmokers compared to the "expected" prevalence is obscure. It is possible that selection factors are more important for smokers than nonsmokers. The finding that smokers and nonsmokers have approximately the same prevalence of acute health complaints may favor this view. The possibility of smoking as a masking factor should also be considered.

Karmøy is a flat island on the west coast of Norway, with minor general air pollution. Oslo is the capital of Norway with 500,000 inhabitants and a higher degree of air pollution than Karmøy. A normal male population of Karmøy will probably have a lower prevalence of respiratory symptoms than a corresponding male population of Oslo, but the difference is probably only slight (5). Both this study and the Oslo study (3) were based on questionnaires filled out by the respondents themselves, and the questions on respiratory symptoms were identical. We therefore believe that a comparison between the two studies is valid.

A cross-sectional study such as this one will have a tendency to underestimate the possible adverse effects of the work environment because of the primary and secondary "healthy worker effects." Therefore it is possible that this study underestimates the risk of developing respiratory symptoms of a chronic, recurrent nature among primary aluminum workers.

The question of chronic pulmonary disease and aluminum production has been raised by several investigators previously (6), and it is still being disputed. Some authors believe that there may be a connection between repeated acute respiratory complaints and the development of chronic lung disorder (11). This study supports the assumption that the use of recovery alumina could be a risk factor when compared to pure alumina. This question still remains to be answered however.

\section{Acknowledgments}

The authors wish to thank the workers and management of Norsk Hydro A/S, Karmøy Fabrikker and co-workers of the Institute of Occupational Health for help with the planning and execution of the investigation and $\mathrm{K}$ Halgard and $\mathrm{Y}$ Thomassen of the Institute of Occupational Health for performing the analyses of PAH and trace elements, respectively.

\section{References}

1. Bjørseth A, Bjørseth $\mathrm{O}$, Fjeldstad PE. Polycyclic aromatic hydrocarbons in the work atmosphere: I. Determination in an aluminum reduction plant. Scand $j$ work environ health 4 (1978) 212-223. 
2. Bjørseth A, Bjørseth O, Fjeldstad PE. Polycyclic aromatic hydrocarbons in the work atmosphere: II. Determination in a coke plant. Scand j work environ health 4 (1978) 224-236.

3. Gulsvik A. Obstructive lung disease in an urban population. Department of Lung Diseases, The National Hospital, University of Oslo, Oslo 1979.

4. Gylseth B, Jahr J. Some hygienic aspects of working in aluminum reduction potrooms with special reference to the use of alumina from the dry cleaning process of Søderberg potgases. Staub-Reinhalt. Luft 35 (1975) 430-432.

5. Haenszel W, Hougen A. Prevalence of respiratory symptoms in Norway. $\mathrm{J}$ chronic dis 25 (1972) $519-544$.

6. Hughes JP, ed. Health protection in primary aluminum production: Proceedings of a Seminar, Copenhagen 29-30 June 1977. IPAI.

Received for publication: 18 November 1980
7. Jahr J, Lie A. Mowé G. The work environment in the potrooms at Ardal and Sunndal Verk A/S [in Norwegian]. Institute of Occupational Health, Oslo 1979. (HD 808/79).

8. Johannessen $J$, Bergan-Skar B. Itching problems among potroom workers in factories using recycled alumina. Contact dermatitis 6 (1980) $42-43$

9. Miettinen OS. Epidemiologi. Yrkesmedisinska kliniken. Regionsjukhuset in Ørebro and Arbetarskyddsfonden, Ørebro 1975.

10. Milham S. Mortality in aluminum reduction plant workers. J occup med 21 (1979): 7, 475-480.

11. Mowé G. Working conditions and health problems among potroom workers at Norsk Hydro A/S, Karmøy Fabrikker [in Norwegian]. Institute of Occupational Health, Oslo 1976. 